\title{
Aneta Rogalska-Marasińska
}

Uniwersytet Łódzki

\section{Edukacja międzykulturowa w obrazach Siła humanistycznego przekazu emanująca z „National Geographic”}

\begin{abstract}
Żyjemy w trudnych czasach. W życiu wewnętrznym człowieka, podobnie jak w życiu zbiorowym wzrasta chaos. Straciliśmy płodną wiarę w zasady, które mogłyby tworzyć ład; musieliśmy zwątpić w hasła, które zawiodły. Fanatyzm różnych obozów, wyzyskując ten niepokój, wkrada się do serc ludzkich i sprawia, że stają się one twarde, wzajemnie sobie wrogie i ponad wszelką miarę pewne swego.

Jeśli jednak nie mamy zwątpić w człowieka i w sens życia w ogóle, musimy szukać dróg wyjścia, zarówno z chaosu, jak i z zaślepień.
\end{abstract}

Bogdan Suchodolski

\section{Wstęp}

Bogdan Suchodolski sformułował cytowaną myśl dokładnie 70 lat temu ${ }^{1}$. Niestety do dziś nie straciła nic ze swej aktualności. Mimo wszystko, łącząc się $\mathrm{z}$ Profesorem $\mathrm{w}$ nadziei, a nawet $\mathrm{w}$ przekonaniu, $\mathrm{w}$ istniejące jeszcze pokłady pozytywnych i twórczych sił oraz możliwości człowieka, wierząc w humanistyczny wymiar jego różnorodnej aktywności, chciałabym zaproponować pewne rozważania, poszukując treści edukacyjno-wychowawczych w przestrzeni komunikacyjnej, jaką stanowią czasopisma. Wyróżniam zatem dwie zasadnicze grupy problemowe:

1) Jakie miejsce wobec wyzwań współczesności, a tym samym - w kształceniu człowieka powinna zajmować edukacja międzykulturowa?

2) Jaką rolę w budowaniu wiedzy czytelników spełnia nieprzerwanie od 1888 r. amerykański miesięcznik geograficzny „National Geographic”?

\footnotetext{
${ }^{1}$ B. Suchodolski, Skad i dokqd idziemy. Przedmowa, Warszawa 1999, s. 5, I wyd. - 1939.
} 


\section{Edukacja międzykulturowa jako droga ku drugiemu czlowiekowi}

Edukacja międzykulturowa to edukacja humanistyczna, dla której centrum poszukiwań badawczych skupia się wokół człowieka i jego relacji z otoczeniem. Przedrostek „między” wskazuje na pewną przestrzeń, która powinna pojawić się pomiędzy kulturami i jednocześnie powinna je łączyć, a nie dzielić. Posługując się językiem matematyki, interpretuję ją jako część wspólną dwóch zbiorów. Ja $\mathrm{z}$ własną kulturą stanowię jeden zbiór, drugi reprezentuje przedstawiciela innej społeczności. Taka sytuacja zapewnia mi komfort pozostania „u siebie” i jednocześnie wchodzenia w odmienny świat. Użycie liczby pojedynczej też nie jest tu przypadkowe. Jak pisał Hans Georg Gadamer, człowiek buduje dwa typy relacji: ,ja-świat” i ,ja-ty”. „Ty” jest zdaniem filozofa szczególnie ważne dla wszelkiego samopoznania i samozrozumienia. I wcale nie chodzi o całkowite zrozumienie „Ty”, „lecz to, co owo Ty mówi nam prawdziwego"”.

Spotkanie po drugiej stronie, naprzeciwko nas, człowieka ma, zgodnie $\mathrm{z}$ hermeneutycznym podejściem H. G. Gadamera, kluczowe znaczenie. Chodzi w nim o taką sytuację, w której chcemy postrzegać owego człowieka jako osobę, a nie obiekt, z którym podejmiemy rywalizację, walkę lub który „w najlepszym razie" jest nam obojętny. Potrzebna jest natomiast postawa charakteryzującą się życzliwym zaciekawieniem i otwartością (a nie egzaltowana, powierzchowną pseudoprzyjaźnią i pseudoserdecznością). Takie świadome spotykanie na swojej drodze innych ludzi, poszukiwanie ich lub nieodtrącanie okazji wchodzenia $\mathrm{z}$ nimi $\mathrm{w}$ interakcje jest szansą na nasz szczególny rozwój. Szczególny, gdyż połączony z odrywaniem się od rutyny i monotonii, i umożliwiający wznoszenie się ponad codzienność. Silne emocje i głębokie przeżywanie towarzyszące takiemu spotkaniu sprawiają, że staje się ono dla nas istotne, nadajemy mu sensy i znaczenia, wczytujemy się w nie i na miarę naszych możliwości (które mogą być niewielkie, ale i też bardzo duże - zwykle zależy to od nas samych) interpretujemy. Tak zinternalizowane już z nami pozostaną, rozwijając naszą osobowość, poszerzając wiedzę, inicjując stawianie nowych celów, umożliwiając odbieranie lub wartościowanie faktów, sytuacji, czynów w sposób dla nas przekształcony lub zupełnie nowy.

Dla szeroko rozumianego procesu wychowania postrzeganego z perspektywy edukacji ustawicznej, całożyciowej, a w przypadku rozważań ograniczonych do publikacji czasopiśmienniczych, realizowanego także poza instytucjami oświatowymi warto, myślę, spróbować określić znaczenie i właściwe miejsce wiedzy potocznej, wpisującej się $\mathrm{w}$ wiele koncepcji rozumienia wiedzy na przestrzeni wieków i interpretowania jej przez różnorodne dyscypliny nauki.

Dychotomia tego, co jest wiedza, a co nią nie jest, zaprzątała już umysły starożytnych filozofów. Arystoteles, ukazując drogi, którymi dusza poznaje

\footnotetext{
${ }^{2}$ H. G. Gadamer, Prawda i metoda, Warszawa 2007.
} 
prawdę, tj. gdy przyjmuje coś lub odrzuca (twierdząc coś lub przecząc), wymienia pięć trwałych dyspozycji. Są to: „sprawność techniczna, wiedza naukowa, rozsądek czyli mądrość praktyczna, mądrość teoretyczna czyli filozoficzna i myślenie intuicyjne"3.

Rozsądek, który filozof określa jako fronesis, traktuje jako praktyczną dyspozycję człowieka do działania, opartego na trafnym rozważeniu tego, co dla niego jest dobre, a co złe. Możemy więc mówić o indywidualnej (tj. ostatecznej) i konkretnej dyspozycji człowieka do poznania (dochodzenia do prawdy) za sprawą postępowania moralnego. Arystoteles przekonuje: „Z powyższych więc wywodów wynika, że nie podobna być we właściwym tego słowa znaczeniu dzielnym etycznie, nie będąc rozsądnym - ani też rozsądnym bez dzielności etycznej"4.

W interpretacji H. G. Gadamera przesłanie Etyki nikomachejskiej dotyczy: „właściwego ustalenia roli, jaką ma do odegrania rozum w postępowaniu moralnym", Dlatego dla H. G. Gadamera odczytującego Arystotelesa ważne jest rozróżnienie między episteme a fronesis. Episteme jest teoretyczną wiedzą przedmiotową, która nie angażuje człowieka. Natomiast w przypadku fronesis, czyli wiedzy moralnej, sytuacja poznającego podmiotu jest całkowicie inna. Człowiek nie może oddzielić się od poznawanych faktów. „To coś przezeń poznawanego bezpośrednio go dotyczy" mówi filozof ${ }^{6}$.

Zgoda na dopuszczenie Innego z własną kultura, aprioryczne otwarcie mu własnych drzwi daje szansę na nasz wielostronny rozwój, który zostaje poszerzony o jego perspektywę. Oczywiście w problematyce edukacji międzykulturowej pojawia się zagadnienie posiadania przez każdego własnego terytorium kulturowego, tj. pewnego uniwersum określonego przez tradycję kulturową, spuściznę symboliczną, wzorce osobowe, etos wychowawczy, normy postępowania i wreszcie cały system wartości określający, porządkujący i dający podstawę do oceny jednostki. Mówimy więc o pewnych granicach kulturowych, które w konsekwencji kontaktów z przedstawicielami innych kultur będą się zapewne zmieniać. Mogą się rozluźniać, otwierać, gdzie indziej za to wzmacniać. Wynika to z bardzo istotnego dla rzeczywistych relacji międzykulturowych określania i dookreślania siebie, własnej tożsamości, uświadamiania sobie „kim jestem?" jako członek tej społeczności, którą reprezentuję. Wiedza wzmocniona wewnętrzną zgodą na siebie i duma z tego kim się jest sprawiają, że wiem, które obszary mojej kultury mogą rozwinąć się i otworzyć, a które muszę chronić, pielęgnować, zachowywać takimi, jakimi są, gdyż inaczej stracą swą moc i unikalność, przepadną, zaginą.

\footnotetext{
${ }^{3}$ Arystoteles, Etyka nikomachejska, thum., wstęp i komentarz D. Gromska, Księga VI O trwatych dyspozycjach prowadzacych do poznania prawdy, Warszawa 2007, s. 195.

${ }^{4}$ Ibidem, ks. VI - O dzielności etycznej wrodzonej i w znaczeniu wtaściwym, s. 209.

${ }^{5}$ H. G. Gadamer, Prawda ..., Warszawa 2007, s. 427.

${ }^{6}$ Ibidem, s. 430.
} 
Przyjęcie humanistycznej postawy zakłada, że druga strona myśli podobnie. Dialog międzykulturowy jest wtedy możliwy, gdy obie kultury traktują się po partnersku, oferują własny dorobek i jednocześnie mogą korzystać z przestrzeni kulturowej Innego. Edukacja międzykulturowa proponuje więc paradygmat współistnienia, który zakłada możliwość wspólnego rozwoju i odnoszenia korzyści postrzeganych w kategoriach humanistycznego rozwoju człowieka. Komunikacja międzykulturowa wyzwala porównywanie, uświadamia nam, w czym między sobą się różnimy, a gdzie jesteśmy podobni. Niektóre różnice, ale też i podobieństwa okazują się pozorne (np. to, że stanowimy społeczność Unii Europejskiej nie oznacza, że kultury, które reprezentujemy, choć posiadają ten sam trzon śródziemnomorsko-chrześcijański, są jednakowe). Dlatego wzajemne dowiadywanie się o sobie, weryfikowanie wiedzy, którą się najczęściej posługujemy (tj. wiedzy potocznej) i jej pogłębianie, przełamywanie barier i sprawdzanie stereotypów, to chyba najlepsza droga do wspólnego odkrywania się. Właśnie odkrywania, a nie podboju, dominacji, zagłady. Przyjęcie takiej postawy daje nam szansę na bezpieczniejsze, choć wcale nie łatwiejsze, przedostawanie się na drugą stronę. Jak podróżnik rozpoczynający wyprawę powinniśmy zadać sobie pytania: Co znajduje się dalej, poza naszym horyzontem kulturowym? Co tam znajdziemy, odkryjemy? Kogo spotkamy? Co nas zaskoczy, ile jest niewiadomych? Jakie niebezpieczeństwa na nas czyhają i jak ich, dobrze się przygotowując, uniknąć?

„Uczyć się, aby żyć wspólnie. Uczyć się współżycia z Innymi” to niewątpliwie znaczace przesłanie i jeden $\mathrm{z}$ fundamentalnych celów edukacji XXI w. Parafrazując tytuł Raportu ${ }^{7}$, możemy powiedzieć, że w edukacji międzykulturowej ukryty jest skarb, który należy pielęgnować i rozwijać tak, abyśmy my sami stawali się bogatsi o działania i przeżycia, których ów skarb jest źródłem.

\section{„National Geographic" - czasopismo zachęcające do humanistycznej refleksji}

„National Geographic Magazine”, w skrócie „National Geographic” jest miesięcznikiem, który nieprzerwanie ukazuje się od 1888 r. Jest on oficjalną i główną publikacją amerykańskiego Towarzystwa Geograficznego o nazwie National Geographic Society. Towarzystwo zostało założone 13 stycznia $1888 \mathrm{r}$. przez 33 odkrywców i naukowców, którzy zebrali się w prywatnym klubie Cosmos $\mathrm{Club}^{8}$ w Waszyngtonie. Grupie przyświecało pragnienie: „pogłębiania

\footnotetext{
${ }^{7}$ Por. Raport dla UNESCO Międzynarodowej Komisji do spraw Edukacji dla XXI wieku, pod przewodnictwem J. Delorsa Edukacja. Jest w niej ukryty skarb, Warszawa 1998.

${ }^{8}$ Cosmos Club - elitarny klub założony w 1878 r. w Waszyngtonie. Wśród celów przyświecających powołaniu organizacji do życia było wspieranie rozwoju jego członków w dziedzinie nauki, literatury i sztuki. Członkowie klubu wielokrotnie byli laureatami nagród, takich jak:
} 
i rozprzestrzeniania wiedzy geograficznej przy jednoczesnym promowaniu ochrony światowego dorobku kulturalnego i historycznego oraz dziedzictwa i zasobów naturalnych"'.

Dziś również zarząd Towarzystwa, które jest jedną z największych pozarządowych instytucji naukowych i edukacyjnych na świecie, składa się z 33 członków, wśród których znajdują się szanowani pedagodzy, przedstawiciele biznesu, byli członkowie rządu oraz przedstawiciele ochrony środowiska. Dlatego też Towarzystwo skupia swoją uwagę na problematyce z zakresu geografii, archeologii, nauk przyrodniczych, ochrony zabytków i środowiska oraz porusza kwestie dotyczące wyzwań międzykulturowych (w wymiarze historycznym i w zakresie dorobku kulturowego). Współczesne motto działalności Towarzystwa to: „Inspiring people to care about the planet” ${ }^{\text {10 }}$.

Pierwszym prezydentem Towarzystwa Geograficznego był Gardiner Green Hubbard (1822-1897) - amerykański prawnik, finansista i filantrop. Znaczącą rolę pełnił też w Clarke School of the Deaf - pierwszej w USA szkole dla głuchych dzieci w Northampton w Massachusetts, gdzie stosowano nowoczesne metody kształcenia osób z takim defektem. G. G. Hubbard był także jednym z założycieli i pierwszym prezydentem Bell Telephone Company $(1877)^{11}$. Na cześć swojego prezydenta National Geographic Society przyznaje medal, tzw. Hubbard Medal, za szczególne prace archeologiczne, odkrycia i badania. Do 2000 r. medal wręczono 34 razy.

Drugim prezydentem Towarzystwa Geograficznego został zięć G. G. Hubbarda - Aleksander Graham Bell (1847-1922) - naukowiec, wynalazca, inżynier, „ojciec” telefonu ${ }^{12}$, profesor uniwersytetu w Bostonie, nauczyciel w szkole dla głuchych. W 1877 r. poślubił córkę G. G. Hubbarda, Mabel Gardiner Hubbard (1857-1923), z którą miał dwie córki Elsie May Bell (1878-1964) i Marian oraz dwóch synów, którzy jednak zmarli w dzieciństwie. A. G. Bell, człowiek o niezwykłym umyśle i szlachetnym sercu, starał się zawsze wspomagać innych. Znaczącą część swojej aktywności zawodowej i osobistej poświęcił pracy z osobami głuchymi. Jego matka zaczęła głuchnąć, gdy miał zaledwie 12 lat. Żona z kolei ogłuchła jako 3-letnia dziewczynka po przebyciu szkarlatyny. Mabel była początkowo uczennicą A. G. Bella w szkole dla dzieci głuchych.

Nagroda Nobla i Nagroda Pulitzera. Odznaczani też byli prezydenckim Medalem Wolności. Co jednak zaskakujące, przez 110 lat swojego istnienia, tj. aż do 1988 r., klub był organizacją zrzeszającą wyłącznie mężczyzn. Kobiety nie tylko, że nie mogły zostać jej członkami, ale nawet jako goście nie mogły wchodzić głównym wejściem!

${ }^{9}$ www.nationalgeographic.com [02.10.2009].

${ }^{10}$ Tłum. własne: Pobudzanie ludzi do troski o nasza planete, www.nationalgeographic.com [02.10.2009].

${ }^{11}$ Bell Telephone Company założono 9 lipca 1877 r., a ślub Mabel i Aleksandra odbył się 11.02.1877 r.

${ }^{12}$ Co ciekawe, to właśnie telefon A. G. Bella był pierwszym wynalazkiem opatentowanym w USA. 
Trzecim z kolei prezydentem National Geographic Society w latach 1920-1954 był zięć państwa Bellów, urodzony w Turcji Gilbert Hovey Grosvenor (1875-1966). Żoną jego była starsza córka Bellów, Elsie May Bel1 ${ }^{13}$. G. H. Grosvenor został pierwszym rzeczywistym wydawcą „National Geographic Magazine" i pełnił swoją funkcję przez 55 lat (1899-1954)! Uważany jest on także za pionierskiego autora fotoreportaży, które wraz z tekstami stworzyły jedyne w swoim rodzaju czasopismo geograficzno-kulturowo-edukacyjne.

Należy jednak od razu zaznaczyć, że czasopismo, jakie znamy, tj. o pięknych zdjęciach i osobistych reportażach, $\mathrm{z}$ charakterystyczną żółtą ramką na okładce, początkowo wyglądało zupełnie inaczej. Powołano je do życia z innych powodów. „National Geographic Magazine” był pierwotnie periodykiem naukowym. Zawierał specjalistyczną wiedzę ujętą w poważne artykuły. Szata graficzna była uboga, a okładka przytłaczała swym ponurym, rudawym kolorem. Krag czytelników ograniczał się do ścisłego grona specjalistów i szybko okazało się, że pismo zaczęło być nierentowne. Liczba odbiorców malała, magazyn ukazywał się w coraz skromniejszych nakładach ${ }^{14}$. Kiedy do zespołu redakcyjnego przybył G. H. Grosvenor, dostrzeżono ,światło w tunelu” i nową szansę dla magazynu. Po pierwsze młody redaktor uznał, że należy zmienić okładkę pisma oraz sam jego charakter. $Z$ propozycji stricte naukowej należało odejść na rzecz wydawnictwa popularno-naukowego. Po drugie uznano, że historie będą „opowiadane” głównie za pomocą zdjęć.

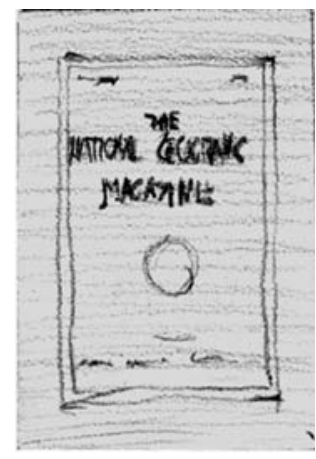

Rys. 1. Pierwsza okładka NGM z 1888 r. (bardzo uboga szata graficzna), rys. C. Marasiński na podstawie zdjęcia okładki, por. www.coverbrowser.com/ cevers/national-geographic, \# 1-49, \# 1 [04.10.2009]

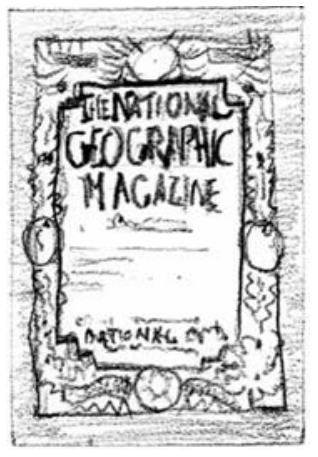

Rys. 2. Okładka NGM z września 1939 r. (pełny wieniec dębowo-laurowy), rys. C. Marasiński na podstawie zdjęcia okładki, ibidem, \# 550-599, \# 563 [04.10.2009]

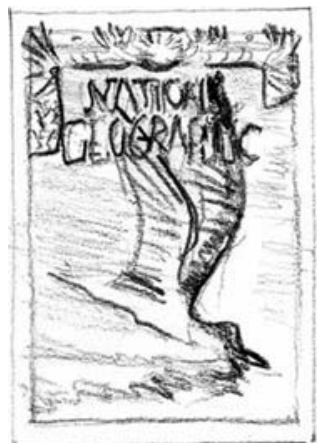

Rys. 3. Okładka NG z maja 1970 r., rys. C. Marasiński na podstawie zdjęcia okładki, ibidem, \# 850-899, \# 892 [04.10.2009]

\footnotetext{
${ }^{13}$ Kolejni dwaj prezydenci Towarzystwa to syn i wnuk Grosvenorów - Melvill Bell Grosvenor i Gilbert Melvill Grosvenor.

${ }^{14}$ Warto nadmienić, że do niedawna w USA, inaczej niż w Europie i innych krajach na świecie, „National Geographic” można było kupić tylko w formie prenumeraty.
} 
I tak, przełom wieku XIX i XX był dla czasopisma okresem znaczących zmian. Okładka kilkakrotnie przechodziła metamorfozę. Jeszcze w XIX stuleciu zyskała bardziej pastelową barwę, pojawił się na niej spis treści całości wydania, a w tle umieszczono siatkę południków i równoleżników. W 1900 r. powrócono do ascetycznej formy okładki w kolorze piaskowo-szarym. Nie trwało to jednak długo i wkrótce zaczęto wprowadzać łagodne, roślinne elementy, typowe dla propozycji artystycznych Art Nouveau. W 1910 r. pojawia się na okładce charakterystyczna żółta ramka, choć na zdjęcia trzeba będzie jeszcze poczekać (niemalże 50 lat). Tymczasem „młodopolskie” elementy plastyczne ustępują miejsca wieńcowi dębowo-laurowemu, którego szczątkowe fragmenty odnajdziemy i dziś, w najbardziej aktualnych numerach. Natomiast co do zawartości merytorycznej i charakteru tekstów magazynu przełomowym momentem był rok 1905. Wtedy bowiem, już w styczniowym wydaniu, ukazał się artykuł o Tybecie uzupełniony wieloma pełnostronicowymi zdjęciami. Autorami obrazów byli dwaj badacze pochodzący z Imperium Rosyjskiego - Gombojab Tsybikow i Owsze Norzunow, którzy w latach 1900-1901 prowadzili tam swoje prace. Od tego czasu oprócz artykułów na temat szeroko rozumianego środowiska przyrodniczego, historii i aktualnych wydarzeń rozgrywających się w najdalszych zakątkach Ziemi czasopismo stało się rozpoznawalne za sprawą doskonałej jakości zdjęć. Za cel przyjęto bowiem ich standard albumowy, a nie gazetowy.

Od początku lat dwudziestych XX w. wprowadzono technologię fotografii kolorowej, choć była ona jeszcze bardzo rzadka. Wcześniej natomiast umieszczano już zdjęcia, w których kolory uzyskiwano przez barwienie fotografii czarno-białych. Od lat trzydziestych XX w. autorzy tekstów i zdjęć zaczęli używać małych, $35 \mathrm{~mm}$ aparatów fotograficznych wyposażonych w filmy firmy Kodak. W czasach najnowszych, podążając za jakością obrazu, fotoreporterzy „National Geographic” zaczęli posługiwać się technologią cyfrową. Dziś wydawca nie musi promować czasopisma przez podkreślanie liczby zamieszczonych w nim kolorowych zdjęć. Wcześniej tak właśnie czyniono. Na przykład, numer z września 1939 r. zawierał aż 32 strony ilustracji w pełnym kolorze odpowiednią adnotację umieszczono na okładce publikacji.

Wydarzenia II wojny światowej i przystąpienie USA do działań zbrojnych odcisnęły swoje piętno na magazynie. W numerze czerwcowym z 1942 r. na okładce pojawia się pierwsza kolorowa ilustracja - jest nią flaga Stanów Zjednoczonych. Magazyn zachęca także do kupowania oszczędnościowych bonów wojennych. Taki bon możemy zobaczyć na okładce wydania z lipca $1944 \mathrm{r}$. Przez dalsze lata czterdzieste i pięćdziesiate XX w. w czasopiśmie proponowano z powrotem okładkę tekstową, dopiero we wrześniu 1959 r. umieszczono rysunek samolotu należącego do amerykańskiej marynarki wojennej. Miesiąc później, tj. od października 1959 r., rozpoczyna się era kolorowych, pogodnych okładek. Pojawiają się rysunki i zdjęcia o typowej dla „National Geographic” tematyce, którą moglibyśmy syntetycznie ując jako: ludzie, miejsca, zdarzenia, przyroda. Ilustracje wypełniają jednak stale tylko część powierzchni okładki. 
Pierwsze pełne zdjęcia pojawiają się w styczniu 1962 r., a od lipca 1979 r. magazyn ustala zewnętrzną szatę graficzną znaną nam do dziś - żółta, wyrazista ramka, duże zdjęcie w jej środku i skrócony spis treści gdzieś z boku.

Artykuły ostatnich dwóch dziesięcioleci XX w. układane były w pewne serie tematyczne lub skupiały się wokół wybranego, kluczowego problemu. Wśród nich należy wymienić: środowisko, rabunkową gospodarkę leśną, zanieczyszczenia chemiczne, globalne ocieplenie, zagrożone gatunki zwierząt i roślin, a także metale i kamienie szlachetne, produkcję rolną, odkrycia archeologiczne. Czasami cały numer poświęcony był jednemu państwu, zagrożonym, nieodnawialnym źródłom naturalnym lub innej, palącej kwestii.

Aby zwieńczyć moje rozważania nad potrzebą prowadzenia szerokiej i ustawicznej edukacji międzykulturowej chciałabym przedstawić trzy artykuły, które pochodzą z trzech różnych numerów „National Geographic” z lat dziewięćdziesiątych XX w. ${ }^{15}$ Wszystkie ukazują człowieka, mieszkańca Ziemi w podobnych (lub możliwych) do naszych sytuacjach życiowych: 1) ślub, 2) odbudowa kraju i własnego życia po zniszczeniach i doświadczeniach wojennych oraz 3) praca.

\section{Brides of the Sahara-Saharyjskie panny mtode} (February 1998) ${ }^{16}$

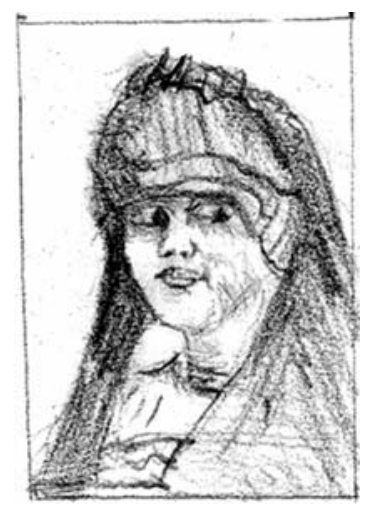

Rys. 4. Młoda dziewczyna z plemienia Tuaregów, rys. C. Marasiński na podstawie zdjęcia, „National Geographic", February 1998, vol. 193, no. 2, s. 83.
Artykuł ujęty jest w najbardziej typową dla ,National Geographic" formułę. Piękne zdjęcia, krótkie teksty i uchwyceni w kadrze aparatu ludzie - tym razem państwo młodzi i ich goście weselni, którzy pragną, aby ten czas był szczególnie uroczysty, wyjątkowy i odświętny. $Z$ treści artykułu dowiadujemy się, że śluby wśród Tuaregów - Błękitnych Jeźdźców Pustyni - odbywają się od czerwca do sierpnia, każdy trwa tydzień, a po zakończeniu ceremonii weselnej młodzi mieszkają przez cały rok w domu panny młodej. W tym czasie małżonek musi zyskać sobie przychylność rodziców swojej żony, w szczególności teściowej. Dąży więc do takiego stanu przez rzetelną pracę, zaangażowanie, oddanie i okazywanie rodzicom należnego szacunku. Dopiero po dobrze wypełnionym okresie wstępnym młodzi roz-

\footnotetext{
${ }^{15}$ Wszystkie przywołane artykuły zostały opublikowane w języku angielskim. Polska wersja językowa Magazynu National Geographic ukazuje się od października 1999 r.

${ }^{16}$ Por. C. Franklin-Barbajosa, Brides of the Sahara, „National Geographic”, February 1998, vol. 193 , no. 2 , s. 80-91.
} 
poczną samodzielne życie. On wyruszy z karawaną przez pustynię, ona zostanie w domu wychowując dzieci, doglądając zwierząt i codziennie thukąc proso na placki.

Historia zapisana tak wyjątkowymi zdjęciami rzuca na nas swój urok, wciąga nas, odrywa od codzienności i daleko przenosi. Zaczynamy odczuwać suche saharyjskie powietrze, gorący piasek i błękitne niebo. Jesteśmy wśród 500 zaproszonych gości. Dookoła nas jest dużo śmiechu, muzyki, wszędzie pełno rozbieganych dzieci, a nieopodal leniwie odpoczywają wielbłądy. Jemy ryż, daktyle, pieczone mięso. Jest pięknie.

\section{Eritrea Wins the Peace - Erytrea wygrywa pokój (June 1996) ${ }^{17}$}

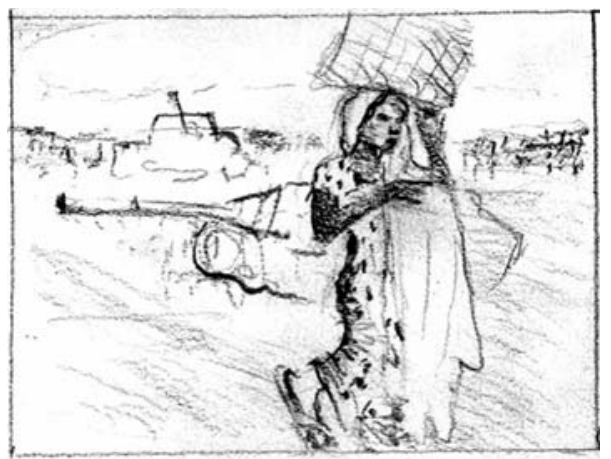

Rys. 5. Mieszkanka Erytrei w drodze na targ, rys. C. Marasiński na podstawie zdjęcia, „National Geographic", June 1996, vol. 189, no. 6, s. $82-83$.
Po 30 latach wojny pomiędzy Erytrea a Etiopią (1961-1991) kraj przedstawia się $\mathrm{w}$ opłakanym stanie. Śmietnisko czołgów, powszechne zniszczenia od bomb, moździerzy i napalmu. Zgliszcza, ruiny, cierpienie. Wracają uchodźcy $\mathrm{z}$ obozów w Sudanie. Przed niepodległym krajem stoi wiele wyzwań i kłopotów. Sami Erytrejczycy podkreślają, że „muszą wszystko zaczynać od poziomu poniżej zera" ${ }^{\prime 1}$. Są niewykształceni (analfabetyzm sięga 80\%), co dramatycznie utrudnia odbudowę własnej ojczyzny. Rusza przemysł, ale wielu ludzi nie jest zdolnych do pracy - plonem kilkudziesięcioletniej wojny są bowiem chorzy i kalecy. Społeczeństwu zagraża przede wszystkim AIDS. Ogniskami choroby są duże miasta, w tym stolica - Asumana, gdzie zarejestrowano $80 \%$ wszystkich przypadków epidemii. Mimo wielu trudności, braków i ogromnego ubóstwa Erytrejczycy są pełni chęci do pracy i z zapałem powtarzają, że mają w sobie „niewyczerpaną determinację"19.

${ }^{17}$ Por. Ch. E. Cobb, jr., Eritrea Wins the Peace, „National Geographic”, June 1996, vol. 189, no. 6 , s. $82-105$.

\footnotetext{
${ }^{18}$ Ibidem, s. 90 .

${ }^{19}$ Ibidem, s. 91.
} 
Pozytywnym efektem wojny jest fakt uzyskania przez kobiety wielu praw i swobód. Chociaż społeczeństwo składa się zarówno z chrześcijan, jak i wyznawców islamu, to tradycyjna pozycja kobiety była do tej pory bardzo niska. Wraz z wolnością uzyskały prawo do rozwodów, głosowania oraz posiadania ziemi. Kiedyś były zamknięte w domach - teraz można je spotkać plotkujące i przechadzające się po ulicach, a nawet odbudowujące drogi. Radość z życia jest wielka, ale zniszczenia są ogromne i niestety częściowo trwałe. Młodzi weterani wojenni, okaleczeni, na wózkach inwalidzkich otrzymali szansę na naukę. W szkole na obrzeżach stolicy uczą się jako bohaterowie. Tak też nazywają ich okoliczni mieszkańcy, którzy przynoszą im codziennie żywność i podarunki, gdyż wiedzą, że mają wobec nich ogromny dług wdzięczności.

\section{Reel to Real - Rolka filmu za rzeczywistość (August 1995) ${ }^{20}$}

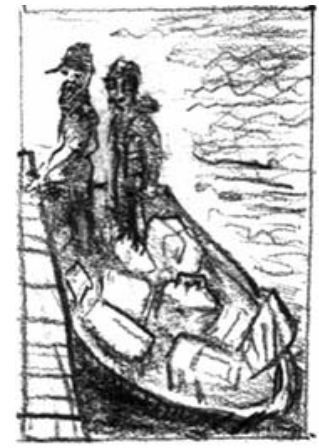

Rys. 6. Fotoreporter Steve Raymer na Alasce (łódź wypełniona ,typowym" zestawem narzędzi do pracy - paczkami ze sprzętem foto), rys. C. Marasiński na podstawie zdjęcia, „National Geographic", August 1995, vol. 188, no. 2, s. 65 .

Artykuł ten jest nieco nietypowy, gdyż pokazuje kulisy pracy tych, których najczęściej nie widzimy, a za to możemy podziwiać efekty ich starań. Fotoreporterzy „National Geographic” to specyficzna grupa zawodowa. Często stają przed zadaniami trudnymi do realizacji, ale jakaś wewnętrzna chęć, potrzeba, a może nawet element szaleństwa zmuszają ich do podejmowania ryzyka i wyrażania zgody na ekstremalne rozwiązania. Na pewno można więc powiedzieć, że nie jest to zwykłe, monotonne zajęcie. Nie ma tu też mowy o rutynie.

Parada w Hiszpanii, monsunowa ulewa w Nepalu czy może oczekiwanie na rekina u wybrzeży Australii? Co dziś wypadnie? Tu nie siedzi się za biurkiem. W pracy fotoreportera liczą się za to wszelkie dodatkowe umiejętności, sprawność fizyczna, odwaga i przeświadczenie o tym, że zajęcie, które wykonują ma sens. Bo przecież warto jest ukryć się pod narzuta, aby nie oswoić małych orłów, albo wisieć na linie, gdy nepalski wieśniak zbiera obok miód dzikich pszczół.

Zazwyczaj w naszej pracy nie dochodzi do tak ekstremalnych wyzwań, ani też, wychodząc z domu, nie zabieramy tylu paczek i walizek. Czy jednak nie ma między naszymi zajęciami pewnych analogii? Warto się nad tym zastanowić.

${ }^{20}$ Por. C. Newman, Reel to Real, „National Geographic”, August 1995, vol. 188, no. 2, s. $58-77$. 


\section{Zakończenie}

Przywołany na początku tekstu B. Suchodolski postulował konieczność szukania dróg wyjścia z chaosu i zaślepień, w jakie popadł dzisiejszy, zagubiony człowiek. Myślę, że odwołanie się do edukacji międzykulturowej ma w tej sytuacji szczególny sens. Poznawanie innych ludzi, konfrontowanie ich realiów życiowych z własnymi, jest niezwykle kształcące. W czym jesteśmy do siebie podobni? Gdzie kryją się między nami różnice? Jakie wyznaczamy sobie cele? Kiedy jesteśmy szczęśliwi? - to pytania, na które warto szukać odpowiedzi.

Codzienne relacje z innymi ludźmi opierają się na naszej wiedzy potocznej. Im będzie ona głębsza, rozleglejsza, coraz bardziej wielowątkowa i otwarta na nowe doznania, tym możliwości naszych reakcji na różnorodne bodźce będą się zwiększały. Zachęcanie współczesnego człowieka do poznawania swojego środowiska życiowego (przede wszystkim: społecznego, kulturowego i przyrodniczego) powinno odbywać się bez przerwy, a zatem także za pośrednictwem czasopism popularno-naukowych. Dochodzenie do prawdy powinno łączyć się $z$ emocjonalnym poruszeniem. Pożądanym by bowiem było, aby to, co człowiek poznaje, uznawał, że bezpośrednio go dotyczy. Uczenie się przez przeżywanie to jeden z cenniejszych sposobów rozwoju człowieka.

Miesięcznik „National Geographic” niewątpliwie jest czasopismem szczególnym. Poruszając kwestie etyczne, umożliwia czytelnikowi budowanie proponowanej przez Arystotelesa osobistej wiedzy moralnej. Umieszczane w periodyku zdjęcia od blisko 110 lat „opowiadają” ludzkie historie w sposób jedyny w swoim rodzaju. Emanują siłą humanistycznego przekazu, który przecież stanowi niezwykle cenne źródło wartościowych i bardzo dziś potrzebnych treści i przeżyć. 